\title{
Możliwość religii
} w obliczu współczesnego pluralizmu

\begin{abstract}
Nowadays, very often in connection with postmodern philosophy, there appears a question of a normative call for pluralism. The argumentation made by postmodernists focuses mostly on the notions of violence and of metaphysics which, according to them, is a theoretical ground for violence. In the following paper we will try to present the possibile justification of this normative call, the reception of this call on Polish and international grounds, and also we will try to present how, in the face of this call, religion can function. To do this we will show concepts of religion; the first concept by Janusz Salamon (not connected to postmodernism) and the second by Gianni Vattimo (strictly postmodern).
\end{abstract}

Keywords: religion, pluralism, contemporary philosophy, postmodernism, Salamon, Vattimo

\section{Współczesny pluralizm}

$\mathrm{M}$ yślenie klasycznej metafizyki to myślenie jedności. W wiekach średnich, wiekach rozkwitu metafizyki, jedność ta wiązała się ściśle z panującą wówczas na całym kontynencie europejskim religią chrześcijańską. Wszystkie wielkie kategorie metafizyczne, transcendentalia - dobro, prawda, piękno - łączyły się w Bogu, który Jeden wszechmocnie panował. W nowożytności natomiast możemy dojrzeć zamiłowanie filozofów do tworzenia wszechogarniających systemów metafizycznych, co wyrażało właśnie wspomniane myślenie jedności przez klasyczną metafizykę. Systemy Hegla, Leibniza, Spinozy czy Kartezjusza miały na celu nic 
innego, jak tylko objąć całą rzeczywistość. Co więcej, myślenie jedności wspierane było przez konkretną sytuację społeczną. Mniejsze zaludnienie, niższy poziom edukacji i w ogóle niższy standard życia wpływały znacząco na podporządkowywanie się retoryce Kościoła, która była retoryką jedności. Owszem, istniały także inne systemy aksjologiczne, światopoglądowe czy religijne, jednak po pierwsze było ich o wiele mniej niż współcześnie, a po drugie nie były one niegdyś aż tak zauważalne jak dziś. Człowiek średniowiecza, renesansu czy żyjący w XVIII wieku nie spotykał się tak często, jak ma to miejsce współcześnie z wyznawcami innych religii czy otwarcie to ogłaszającymi ateistami. Ludzie zaś myślący w inny sposób niż większość, kierujący się inną hierarchią wartości, zachowywali swe poglądy w tajemnicy. Wystarczy przywołać w tym miejscu losy dużej części oświeconych naukowców XVI i XVII wieku czy kobiet żyjących w średniowieczu. Wraz jednak ze zmieniającą się sytuacją społeczną - przyrostem liczby ludzi, podwyższającym się poziomem edukacji - oraz rozwojem filozofii powoli zmieniało się także myślenie. Oczywiście nie sposób stwierdzić, w jakim stopniu odchodzenie od myślenia jedności na rzecz wielości spowodowane było przez przekształcenia społeczne, na ile zaś przez zmiany zachodzące w samej filozofii i zarazem jej rozwój, można jednak stwierdzić z dużym prawdopodobieństwem, że oba te czynniki znacząco przyczyniły się do zmiany sposobu myślenia. Apogeum zaś zmiana ta osiągnęła wraz z nadejściem filozofii postmodernistycznej ${ }^{1}$. Tak zatem jak myślenie jedności związane jest z metafizyką klasyczną, tak również „ponowoczesność i radykalny pluralizm są ze sobą ściśle związane”2. Warto również zauważyć, że współczesny pluralizm, jak pisze Wolfgang Welsch, „nie jest ani skrycie dogmatycznym pluralizmem nauki, ani domorosłym pluralizmem politycznego liberalizmu, lecz pluralizmem otwartym i dogłębnym”3. Pytanie zaś, które jest szczególnie istotne dla tego tekstu, brzmi: w jakim stopniu można dziś, mając na uwadze filozofię postmodernistyczną, głosić religię? Zanim jednak podejmiemy próbę odpowiedzi na nie, należy wpierw ukazać argumenty filozofów postmodernistycznych na rzecz pluralizmu.

Postmodernizm jest oczywiście zjawiskiem niezwykle zróżnicowanym wewnętrznie i trudnym do dokładnego określenia. W tym tekście przyjmuję za filozofów wpisujących się w nurt postmodernistyczny przede wszystkim Richarda Rorty’ego i Gianniego Vattimo (którzy sami odżegnują się od miana filozofów postmodernistycznych). Wydaje się, że postmodernistyczną argumentację na rzecz

1 Jak pisze Zygmunt Bauman: „umysł ponowoczesny o wiele mniej, niż jego nowoczesny kontrahent, podnieca się perspektywą zamknięcie świata w klatce sztywnych kategorii i klarownych podziałów - a jeszcze mniej czuje ochoty, aby klatkę taką uszczelniać i wyposażać w patentowane zamki”. Z. Bauman, Ponowoczesność jako źródło cierpień, Sic!, Warszawa 2004, s. 282.

2 J. Mariański, Pluralizm religijny szansq czy zagrożeniem dla Kościoła, „Wrocławski Przegląd Teologiczny” 2001, nr 9(1), s. 113.

3 W. Welsch, Nasza postmodernistyczna moderna, tłum. R. Kubicki, A. Zeidler-Janiszewska, Oficyna Naukowa, Warszawa 1998, s. 366. 
pluralizmu można podzielić na dwie, w tym kontekście niekoniecznie ze sobą związane, sfery: 1) etyczną i 2) epistemologiczną.

1. Argument wywodzący się z etyki głosi, że pluralizm niezbędny jest do powstrzymania przemocy, którą rodzi jedność.

Filozofowie postmoderny przyjmują, że jedność, podobnie jak rozum, posiada właściwości totalizujące i terroryzujące. Idea jedności może służyć do usprawiedliwienia przemocy wobec ludzi o odmiennych poglądach lub postawach ${ }^{4}$.

Wedle myślicieli postmodernistycznych, takich jak Gianni Vattimo, metafizyka zorientowana na jedność powoduje przemoc, bowiem opresyjnie narzuca innym konkretny system wartości czy konkretne „prawdy”, nie mając, w istocie, do tego prawa. Każdy system metafizyczny, argumentuje Vattimo, zawiera pewien fundament, podstawowe założenie, pewną jedność, do której cały system się sprowadza, a która nie może zostać w żaden sposób udowodniona. Na tej podstawie zaś cały system jest o tyle prawomocny, o ile poważnie traktujemy jego fundament. To natomiast, czy tak czynimy, zależy jedynie od nas, nie ma bowiem żadnego kryterium pozwalającego ustalić, czy fundament ten jest słuszny („prawdziwy”), czy nie. To opresyjny charakter jedności, twierdzi Vattimo, stanowi podłoże wszelkich totalitaryzmów i horrorów, których doświadczał świat zawładnięty konkretną ideologią. Włoski filozof będzie tu miał na myśli nie tylko zbrodnie nazistów III Rzeszy czy komunistów Związku Radzieckiego, ale także chrześcijańskie krucjaty czy współcześnie prowadzony przez wyznawców Islamu jihad 5 .

Nie istnieje podstawa - pisze Vattimo - do podporządkowania się danemu z góry, transcendentnemu porządkowi ani podporządkowania się komuś, kto żądałby od nas posłuszeństwa jedynie w imię tego porządku. W świecie bez podstaw wszyscy są równi, a każda próba narzucenia innym jakiegoś systemu znaczeń to przemoc i opresja, nie może bowiem zyskać uprawomocnienia przez odwołanie się do jakiegoś obiektywnego porządku6.

Vattimo zwraca uwagę przede na wszystkim etyczne, a nie, jak mogłoby się wydawać, teoretyczne powody krytyki metafizyki klasycznej dokonanej najpierw przez Heideggera, a potem Adorna czy Levinasa. To właśnie myślenie jedności, myślenie fundacjonalistyczne, przynależące metafizyce klasycznej, stanowi o jej błędzie i dlatego właśnie, z powodów etycznych, należało tę metafizykę przezwyciężyć (w sensie Verwindung).

${ }^{4}$ U. Bąk, Postmodernizm a religia, „Konteksty Społeczne” 2015, t. 3, nr 1(5), s. 111.

5 Także Taylor zauważa ścisły związek religii i przemocy: „większość religii historycznych była uwikłana w przemoc - od ofiar z ludzi po międzygminne masakry”. Ch. Taylor, A Catholic Modernity, Oxford University Press 1999, s. 28. Tłumaczenie wszystkich fragmentów z języka angielskiego, o ile nie wskazane inaczej, dokonane przez autora.

6 G. Vattimo, Społeczeństwo przejrzyste, tłum. M. Kamińska, Wydawnictwo Naukowe Dolnośląskiej Szkoły Wyższej Edukacji TWP, Wrocław 2006, s. 102. 
[...] fundament, jeżeli jawi się z nieodwracalną oczywistością, nie pozostawiając miejsca na dalsze pytania, staje się niczym władza, która zakrywa i narzuca się, „nie udzielając wyjaśnień”. Tu tkwią również korzenie, w ostatniej analizie, predyspozycji metafizyki do tego rodzaju przemocy, na który kładą nacisk Adorno i Levinas i który często faktycznie jej towarzyszy ${ }^{7}$.

Odpowiedzią postmodernistów na ,jedność” metafizyki jest normatywne wezwanie do pluralizmu, który w przeciwieństwie do jedności nie prowadzi do przemocy. Świat zatem ma być pluralistyczny do granic możliwości, aby tylko uniknąć przemocy powodowanej przez jedność. W związku z takim myśleniem pojawia się etyka redeskrypcji Richarda Rorty’ego, której głównym założeniem jest mnożenie opisów świata dla samego tego mnożenia. To bowiem pozwala na jak najdalsze odsunięcie się od jedności. Stworzona przez Amerykanina wyraźnie postmodernistyczna postać liberalnej ironistki uznaje, „że wyboru pomiędzy słownikami nie dokonuje się ani w ramach neutralnego i uniwersalnego metasłownika, ani też usiłując przebić się przez zjawiska ku temu, co rzeczywiste, lecz po prostu wygrywając nowe przeciwko staremu”" . Niemożliwość wyboru słownika sprawia, że jedyne, co jej pozostaje, to mnożenie kolejnych, nowych słowników, które wystarczy, że sprawią tylko to, iż odsuną ją jeszcze dalej od jednego słownika finalnego.

2. Argument wywodzący się z epistemologii głosi, że pluralizm w pełni wyraża założenie, iż „nie ma prawdy, są tylko interpretacje”, zaś jedność temu założeniu przeczy, bo zawarte w niej jest dążenie do prawdy obiektywnej. Mimo niezwykłego zróżnicowania wewnętrznego postmodernizmu można stwierdzić, że większość myślicieli wpisująca się w ten nurt podziela krytyczne nastawienie wobec klasycznej teorii prawdy. Wydaje się, że jest to niejako spuścizna Nietzschego i Heideggera, z których myśli czerpie wielu filozofów postmodernizmu ${ }^{10}$, a także Gadamera, do którego nawiązuje postmodernistyczna hermeneutyka (np. Vattimo). Klasyczna teoria prawdy stała się przedmiotem krytyki przede wszystkim ze względu na problem przed-rozumienia czy przed-sądów. Argumentowano, że człowiek nie jest w stanie zdystansować się od rzeczywistości i dzięki temu poznać prawdę, ponieważ nie może odrzucić - a czasem nawet w pełni uświadomić sobie - swoich

7 G. Vattimo, Poza interpretacjq, tłum. K. Kasia, Universitas, Kraków 2011, s. 42.

8 R. Rorty, Przygodność, ironia, solidarność, tłum. W. J. Popowski, Spacja, Warszawa 1996, s. 108.

9 Warto w tym miejscu wyjaśnić pewne nieporozumienie, które często towarzyszy tej postmodernistycznej tezie. Zarzuca się bowiem filozofom głoszącym, że „nie ma prawdy, są tylko interpretacje”, że teza ta jest sama w sobie tezą o pewnej prawdzie. Tak jednak nie jest. Otóż, kiedy postmoderniści twierdzą, że „nie ma prawdy, są tylko interpretacje”, sami wygłaszają tylko pewną interpretację i nie roszczą sobie pretensji, aby uznawać tę tezę za prawdę. Jak pisze Vattimo: ,jeśli też, jako dobrzy myśliciele hermeneutyczni, przyznamy, że nie ma faktów, są tylko interpretacje, nawet ta, którą proponujemy, będzie właśnie interpretacją filozoficznego znaczenia hermeneutyki [...]”. G. Vattimo, Poza interpretacjq, s. 12.

10 Do Nietzschego i Heideggera niektórzy dodaliby również Kanta, od niego wywodząc cały postmodernizm. Czyni tak np. S. Hicks w dziele Explaining Postmodernism: Skepticism and Socialism from Rousseau to Foucault, Scholargy Publishing 2004. 
przed-sądów, do których należy między innymi kultura, moralność czy sytuacja społeczna, ale przede wszystkim fakt, że człowiek jest istotą zanurzoną w języku. Jako taki zaś nigdy nie wyjdzie ani poza język, ani poza resztę tego wszystkiego, co składa się na prestrukturę rozumienia. Człowiek zatem może poznawać tylko w pewnym spektrum, w obrębie pewnych granic czy - posługując się terminologią Kuhna - pewnych paradygmatów. U Rorty’ego mamy do czynienia właśnie z takim rozumieniem poznania. Prawda, twierdzi amerykański filozof, możliwa jest jedynie w obrębie paradygmatu. Nie jest to jednak prawda obiektywna, prawda klasycznej metafizyki, a jedynie - a może aż - pewna interpretacja rzeczywistości (przy czym interpretacje są niewspółmierne $)^{11}$. Z tych właśnie powodów Vattimo powie: „dotąd filozofowie wierzyli, że opisują świat, teraz trzeba go interpretować” ${ }^{12}$. Filozofia więc, tak jak nauka, podaje pewną interpretację rzeczywistości, przy czym nie powinna rościć sobie prawa do twierdzenia o tej interpretacji, że jest jedyną możliwą czy jedyną prawdziwą. Nie istnieje bowiem żadne obiektywne kryterium, dzięki któremu moglibyśmy rozsądzić, która z interpretacji jest „bardziej prawdziwa”. W tym znaczeniu upada również idea autorytetu, która związana jest ściśle z klasyczną metafizyką i tradycją chrześcijańską. Biblia na przykład przestaje być już źródłem, dzięki któremu możemy stwierdzić z całą pewnością, co jest prawdą, a co nie. Wydaje się jednak, że wspomniani filozofowie postmodernistyczni nie tyle twierdzą, że prawda obiektywna jako taka nie istnieje, ile że człowiek nie może do niej dojść ze względu na niemożliwość uwolnienia się od przed-sądów. Możliwe jest, że zakładają, iż w pewnej konkretnej sytuacji - na przykład po śmierci - człowiek będzie już w stanie zdystansować się w pełni od rzeczywistości i wtedy również poznanie prawdy będzie możliwe. Obecnie natomiast jedyne, co pozostaje w ludzkiej możności, to interpretowanie. Jak już wspomnieliśmy, problem prawdy wiąże się ściśle z kwestią jedności i wielości. Założenie o istnieniu prawdy obiektywnej implikuje jedność. W metafizyce klasycznej tą prawdą może być Bóg, absolut wpływający na lub determinujący wszystko, co jest. Założenie natomiast istnienia jedynie wielu równie wartościowych epistemologicznie interpretacji implikuje pluralizm. Podsumowując: nie ma pluralizmu przy założeniu prawdy obiektywnej, tak jak nie ma jedności, zakładając interpretacje.

Dla filozofów postmodernistycznych kwestia pluralizmu jest jedną z podstawowych. Wynika to z jednej strony z ich poglądów etycznych, zgodnie z którymi pluralizm miałby stanowić odpowiedź na przemoc, którą rodzi jedność, z drugiej zaś z ich przekonań epistemologicznych, gdzie pluralizm wpisuje się w tezę o niemożliwości dojścia do prawdy obiektywnej, a jedność się tej tezie sprzeciwia. Dotychczas mówiliśmy o pluralizmie w ogóle, jednak będzie nas interesować szczególnie pluralizm w kontekście religii.

11 Por. R. Rorty, Filozofia a zwierciadło natury, tłum. M. Szczubiałka, Spacja, Fundacja Aletheia, Warszawa 1994, zwłaszcza rozdział VII, 2: „Kuhn a niewspółmierność”, ss. 287-297.

12 G. Vattimo, Poza interpretacja, s. 24. 


\section{Problem jedności (religii) w kontekście normatywnego wezwania do pluralizmu}

Wielu współczesnych autorów utrzymuje tezę, że po pierwsze religia w obliczu wezwania do pluralizmu nie jest możliwa, bowiem zawiera w sobie myślenie jedności i prawdy obiektywnej, które nie może zostać zmienione, po drugie zaś, że w ogóle wezwanie to jest nieuprawomocnione. Autorzy ci argumentują, że postmodernizm wyklucza jakąkolwiek religię i powoduje rozpowszechnienie postawy areligijnej, amoralnej i naiwnie pluralistyczno-tolerancyjnej. Jacek Bramorski w artykule Postmodernizm jako wyzwanie dla moralności chrześcijańskiej stwierdza, że

[...] moralność postmodernistyczna, zakładając negację Boga jako prawdy absolutnej i obiektywnej instancji normotwórczej, przyczynia się do upowszechnienia postawy areligijnej w społeczeństwie. Upadek religijnej wartości życia staje się jednym z zasadniczych powodów zagubienia moralnego współczesnego człowieka ${ }^{13}$.

Jedyne zaś formy religijności możliwe w obliczu postmodernizmu to, zdaniem Bramorskiego, „ruch New Age oraz eklektyczne zjawisko tzw. religijnego supermarketu, na które składają się elementy chrześcijańskie, gnostyczne, magiczne, parapsychologiczne, myśl Wschodu, satanizm, spirytyzm, okultyzm, kabała, neopoganizm itp. Wielu postmodernistów nawiązuje do politeistycznego i panteistycznego pogaństwa przez odrzucenie idei osobowego Boga i sakralizację kosmosu. Postmodernistyczny "powrót do sacrum « nie jest powrotem do prawdziwej religii czy mistyki, ale do neutralnej i pluralistycznej mentalności pogańskiej”14. Podobne zdanie, choć wydaje się nie tak radykalne, przedstawia w artykule Postmodernizm a religia Urszula Bąk. Autorka podziela tezę o zwiększeniu się liczby „religii bez Boga”, które są płytkie i służą jedynie zaspokajaniu potrzeb egzystencjalnych, nie są zaś prawdziwą wiarą, w której człowiek trwa całe swe życie. Religie te można zmieniać wraz ze zmieniającymi się indywidualnymi potrzebami czy wręcz kaprysami. Z obu wspomnianych artykułów wyłania się obraz człowieka doby postmodernizmu jako niestałego, zagubionego aksjologicznie poszukiwacza ${ }^{15}$. Z kolei Agnieszka Kołakowska na pytanie „Czy możliwa jest religia postmodernistyczna?”, odpowiada lakonicznie: „Nie”. W dalszej części swojego tekstu postanawia jednak poprzeć swą odpowiedź szeregiem argumentów polegających głównie na obronie

13 J. Bramorski, Postmodernizm jako wyzwanie dla moralności chrześcijańskiej, „Collectanea Theologica” 2002, nr 72(3), s. 78.

14 Ibidem, s. 87.

15 Podobnie człowieka ponowoczesnego charakteryzuje Bauman, określając go mianem turysty: „ponowoczesna strategia życiowa - pisze Bauman - każe unikać jak ognia wszystkiego, co to raz na zawsze, na wieki wieków, aż śmierć nas nie rozdzieli. Postać turysty jest uosobieniem takiego uniku”. Z. Bauman, Ponowoczesność jako źródło cierpień, s. 143. 
klasycznej teorii prawdy albo na krytyce zawłaszczającego i antyreligijnego charakteru postmodernizmu.

Postmodernista - pisze Kołakowska - jednak twierdzi nie tylko, że w żadną prawdę nie wierzy, lecz także, że żadna prawda nie istnieje. [...] Religia postmodernistyczna jest zatem z definicji niemożliwa. Dla postmodernisty religia jest jednym z dwojga: albo czymś, przeciwko czemu postmodernizm z definicji musi walczyć, ponieważ to coś opiera się na pojęciu prawdy i na autorytecie [...] albo po prostu kolejnym ,językiem”, jednym głosem w „pluralizmie głosów”, który należy traktować jak każdy inny. Wtedy religia, pozbawiona pojęcia prawdy, przestaje być religią ${ }^{16}$.

Jak widzimy, u Kołakowskiej, i nie tylko, religia nieodłącznie związana jest z prawdą obiektywną, którą krytykuje postmodernizm. Jako zaś ruch antyreligijny postmodernizm z konieczności nie może być połączony z jakąkolwiek religią. Podsumowując: argumentacja wielu współczesnych autorów na rzecz stosunku wykluczania się między religią i postmodernizmem opiera się w większości albo na pojęciu prawdy jako związanym z religią, albo na krytyce postmodernistycznego wezwania do pluralizmu jako nieuzasadnionego. Pluralizm bowiem, wedle przytoczonych autorów, prowadzi do degeneracji moralnej, światopoglądowej i życiowej.

Wydaje się jednak, że przytoczona wyżej argumentacja wynika z, po pierwsze, selektywnego traktowania tez postmodernistycznych, po drugie, z mieszania ze sobą postmodernizmu jako nurtu filozoficznego z postmodernizmem jako stanem kultury, po trzecie zaś z niezrozumienia semantyki postmodernistycznej, które zastępowane jest czytaniem postmodernistów przez pryzmat kategorii klasycznej metafizyki, co z konieczności prowadzić musi do błędów hermeneutycznych. Jak zobaczymy w kolejnej części tekstu, postmodernistyczny „powrót do sacrum” ma się zgoła inaczej niż przedstawiają to przytoczeni wyżej autorzy. Nie jest to koniecznie płytkie, przygodne zaspokojenie potrzeb, ale faktyczna wiara całkowicie wypełniająca życie ludzkie. Nie jest również tak, że religia niezawierająca pojęcia prawdy przestaje być religią. Należy jednak wpierw spytać, co skłania nas, abyśmy w ogóle starali się szukać religijnej, czyli nieateistycznej, odpowiedzi na postmodernistyczne wezwanie do pluralizmu. Przyjmując bowiem nastawienie podobne do tego, które ukazali przytoczeni wyżej autorzy, moglibyśmy stwierdzić, że roszczenia pluralistycznego nie należy w ogóle traktować poważnie. Wydaje się jednak, że nie należy go bagatelizować z przynajmniej trzech względów. Po pierwsze, dlatego że postmodernizm jest nurtem na tyle obecnym i silnym we współczesnej filozofii. Po drugie, ze względu na sam kształt współczesnego świata, który bezsprzecznie jest światem pluralistycznym - oraz nieustannie dopomina się uznania i pielęgnowania tegoż pluralizmu. Po trzecie zaś, uzasadnienie tez postmodernistycznych - tj. przytoczone wyżej argumenty etyczny i epistemologiczny - dotyczących pluralizmu przeprowadzone jest w sposób logiczny i dobrze

16 A. Kołakowska, Czy możliwa jest religia postmodernistyczna?, https://teologiapolityczna. pl/agnieszka-kolakowska-czy-mozliwa-jest-religia-postmodernistyczna [dostęp: 15.06.2021]. 
uargumentowany, a także dotyczy tak podstawowych kwestii filozoficznych, jak prawda oraz zwraca uwagę na, niezwykle istotny po doświadczeniach II wojny światowej i okresu komunizmu problem przemocy.

Nie tylko filozofowie związani ideowo z postmodernizmem obstają przy pluralizmie. Również niektórzy myśliciele wprost powiązani z religią (chrześcijańską) poświęcają w swych pracach wiele uwagi kwestii pluralizmu i albo starają się zobaczyć w nim szanse dla religii czy znaleźć sposób na dalsze funkcjonowanie religii w świecie pluralistycznym, albo wręcz argumentują na jego rzecz. Jednym z nich jest kanadyjski filozof Charles Taylor. Rozważając zjawisko sekularyzacji, wyróżnia on dwa jej podstawowe typy - sekularyzację społeczną (dotyczącą społecznego nastawienia do religii jako takiej) i polityczną (dotyczącą relacji między państwem i religią) ${ }^{17}$. Sekularyzacja społeczna jest wedle kanadyjskiego myśliciela niepożądana, bowiem prowadzi do coraz bardziej świeckiego nastawienia poszczególnych ludzi żyjących w społeczeństwie i co za tym idzie chaosu aksjologicznego (o to zresztą oskarża się postmodernizm, co uważam za nieuzasadnione). Sekularyzacja polityczna natomiast może przyjąć dwa oblicza: albo republikańskie, albo liberalno-pluralistyczne ${ }^{18}$. W tej kwestii Taylor przyjmuje stanowisko wspierające typ liberalno-pluralistyczny, który zakłada, że państwo zezwala na obecność wszystkich religii w sferze publicznej, zarazem żadnej z nich nie faworyzując. W odróżnieniu od sekularyzacji społecznej, kanadyjski myśliciel wyraźnie akcentuje potrzebę sekularyzacji politycznej o typie liberalno-pluralistycznym ${ }^{19}$. Zgadza się, że współczesny świat już zawiera w sobie wielość i stara się znaleźć sposób na uszanowanie tej wielości na arenie politycznej. „Jednym z najważniejszych wyzwań, które czeka współczesne społeczeństwo jest odpowiedź na pytanie, jak poradzić sobie z moralnym i religijnym pluralizmem”"20. Nie nawołuje zaś do walki z pluralizmem, ponieważ to prowadziłoby do przemocy.

Na gruncie polskim natomiast, z autorów może nie wprost pozytywnie, lecz na pewno nie negatywnie traktujących kwestię pluralizmu można wymienić Janusza Mariańskiego. Zauważa on, że postępująca pluralizacja (w tym kontekście można by również rzec - sekularyzacja) nie może być rozumiana jednoznacznie negatywnie w kontekście religii. Co prawda stanowi ona wyzwanie, lecz nie tyle wyzwanie dla samej religii, ile wyzwanie dla Kościoła, od którego coraz więcej osób zaczyna odchodzić wraz z pluralizacją. Jak pisze Mariański:

[...] nowoczesny pluralizm prowadzi do zachwiania monopolistycznej pozycji instytucji religijnych, czyli Kościołów. Przynależność do jakiegoś Kościoła nie jest już sprawą oczywistą, staje się rezultatem świadomego wyboru²1.

17 Por. Ch. Taylor, J. Maclure, Secularism and Freedom of Conscience, s. 15.

18 Por. ibidem, s. 34.

19 Por. ibidem, s. 104.

20 Ibidem, s. 1.

21 J. Mariański, Pluralizm religijny..., s. 118. 
Jako taki zaś może być on bardziej wartościowy niż nieświadome trwanie w danym Kościele, na przykład ze względów społecznych. O tyle więc pluralizm może prowadzić do umocnienia się religii, choć niekoniecznie w tej samej formie, co dotychczas. Mariański, w przeciwieństwie do przywoływanych wyżej autorów, zwraca uwagę na bardziej transformujący niż degradujący charakter pluralizmu i wcale nie ocenia tego zjawiska negatywnie. Uważa je raczej za fakt, z którym religia musi sobie poradzić, na który religia musi przygotować adekwatną odpowiedź. Oczywiście dla niektórych jednoznacznie negatywnym faktem może być praktyka odchodzenia wiernych od Kościoła. Jednak „z postmodernistycznego punktu widzenia jest to sytuacja normalna, oznaczająca odejście od nadmiernie zinstytucjonalizowanych form religijności w kierunku pluralizmu religijnego (nie degradacja religijności, ale zmiana form religijnych)”22. Mariański traktuje zatem zjawisko pluralizmu jako pewnego rodzaju nieuchronną zmianę, którą należy zwyczajnie przyjąć i spróbować się w niej odnaleźć.

Dokonujące się zmiany w religijności, często określane w Kościele jako kryzys, nie muszą oznaczać upadku religii, niosą one z sobą również pewne szanse i nowe możliwości pracy dla Kościołów w multireligijnym społeczeństwie. Sytuacja religijna staje się do pewnego stopnia „postmodernistyczna”, co bynajmniej nie upoważnia do podawania prognoz jednoznacznie złowrogich dla chrześcijaństwa. Kościół musi być jednak przygotowany na tę nową sytuację różnorodności i swobody światopoglądowej. W warunkach pluralizmu i indywidualizmu religijnego potrzebne są nowe orientacje czy strategie pastoralne, poprzez które Kościół usiłuje wyjść na spotkanie ze współczesną kulturą 23 .

Liberalne nastawienie Mariańskiego nie jest raczej dominującym wśród autorow chrześcijańskich zajmujących się kwestią pluralizmu i związanego z nią postmodernizmu. Nie sposób jednak odmówić temu pewnej chrześcijańskiej pokory. Warto zaznaczyć, że również takie głosy są słyszane zarówno w Polsce, jak i na świecie (choćby w przypadku Charlesa Taylora).

Kwestia pluralizmu religijnego wykracza poza postmodernizm, chociaż niewątpliwie jest z nim ściśle związana. Nie tylko jednak filozofowie sympatyzujący z postmodernizmem opowiadają się za pluralizmem, lecz również myśliciele przedstawiający inne opcje filozoficzne wspierają różnorodność i wielość.

\section{Propozycje religijne zgodne z wezwaniem do pluralizmu}

W tej części przedstawione zostaną dwie koncepcje filozoficzne, które wydają się odpowiadać na postmodernistyczne wezwanie do pluralizmu, przy czym pierwsza jest koncepcją nienawiązującą do postmodernizmu i może godzić w przywołany

22 Ibidem, s. 122.

23 Ibidem. 
wyżej epistemologiczny argument za pluralizmem, zaś druga wpisuje się już w omawiany nurt i respektuje oba argumenty. Co więcej, przykład drugiej koncepcji pozwoli na ukazanie religii niewiążącej się z prawdą obiektywną, lecz wydaje się wciąż pozostającej religią, co wedle przytoczonych wyżej autorów, takich jak Kołakowska czy Bramorski, nie jest możliwe.

Agateizm to stanowisko wypracowane przez Janusza Salamona w artykule Atheism and Agatheism. Sam autor wydaje się je formułować właśnie jako pewnego rodzaju odpowiedź na pluralizm religijny. Salamon w pewnej mierze zgadzałby się z postmodernistami, czy lepiej, z myślą hermeneutyczną, jeśli chodzi w ogóle o istnienie czegoś takiego jak pluralizm.

[...] specyficzna natura przekonań religijnych i również specyficzny charakter języka religijnego połączone z nieuchronnie perspektywicznym, socjohistorycznym usytuowaniem wierzącego jako powiązanego z konkretnymi czasami, miejscami, kulturami i językami muszą wytworzyć różnorodność koncepcji i przekonań religijnych ${ }^{24}$.

Zwrócenie uwagi na fakt ludzkiego uwikłania w różnego rodzaju przed-sądy czy przed-rozumienie jest niemalże identyczny z wnioskami epistemologicznymi takich autorów, jak Heidegger czy Gadamer. Co jeszcze bardziej świadczyć może o zgodzie twórcy agateizmu z koncepcją hermeneutyczną podzielaną przez postmodernistów, to przekonanie, że „wierzący uwikłani są w koło hermeneutyczne i nie mogą transcendować swych ludzkich warunków, aby faktycznie osiągnąć »widok znikąd« czy »perspektywę boską" [...]”25. Niemożliwość dystansu ze względu na przed-sądy jest jedną z kluczowych tez zarówno Heideggera, jak i Gadamera, a także później wielu postmodernistów, takich jak Vattimo. Można zatem stwierdzić, że przyczyny pluralizmu Salamon dopatruje się, podobnie do myśli hermeneutycznej i postmodernistycznej, w nieistnieniu obiektywnego kryterium, dzięki któremu można by było stwierdzić, które z przekonań są „bardziej prawdziwe”. W tekście Atheism and Agatheism można jednak również zauważyć odniesienie się autora do takich kategorii, jak „najwyższe dobro” czy „ostateczna rzeczywistość”, co przywodzi na myśl określenia używane przez metafizykę klasyczną, która z powyższą tezą kategorycznie się nie zgadza i w przeciwieństwie do hermeneutyki i postmodernizmu zakłada możliwość dystansu.

Salamon przywołuje, za Thornhill-Millerem i Millicanem, dwa „typy” religii: pierwszego i drugiego rzędu. Religie pierwszego rzędu to „faktyczne religie historyczne. Religie drugiego rzędu miałoby by być rodzajem »wąskiego« teizmu czy deizmu (być może zbyt wąskiego, jak będę twierdził, żeby móc je nazywać religią) [...]”26. Religie pierwszego rzędu charakteryzuje większa konfliktowość

24 J. Salamon, Atheism and Agatheism, „European Jurnal for Philosophy of Religion” 2015, nr 7(4), s. 232.

25 Ibidem, s. 236.

26 Ibidem, s. 199. 
(wydaje się, że jest tak, ponieważ za najważniejszą wartość biorą one prawdę zamiast dobra), podczas gdy religie drugiego rzędu cechują się większą tolerancją i w większym stopniu umożliwiają pluralizm. Agateizm natomiast wychodzi poza te kategorie. Jest to system utożsamiający Boga (ostateczną rzeczywistość) z najwyższym dobrem ${ }^{27}$. Owa ostateczna rzeczywistość jest tu również traktowana jako podstawa i cel wszystkiego, co dobre, dzięki czemu możliwa jest teleologicznie ukierunkowana aksjologia. Istotne jest to, że agateizm sam w sobie nie pretenduje raczej do miana religii, lecz stanowi raczej możliwą podstawę wielu różnych systemów religijnych ${ }^{28}$. Agateizm ma zatem być dobrą alternatywą dla religii drugiego rzędu, ponieważ z jednej strony jest w nim zgoda na pluralizm, z drugiej zaś nie jest tak rozmytym, czy „wąskim” systemem, jakim często bywają religie drugiego rzędu (które przez Salamona są nazywane po prostu „poglądami metafizycznymi”). Warto również wspomnieć, że agateizm sam dostarcza wyjaśnienia faktu pluralizmu, które niezwiązane jest z wcześniej przywoływanym. Salamon twierdzi, że źródłem przekonań religijnych jest wyobraźnia agatologiczna, ukierunkowana na Boga świadomość moralna. Jako że istnieją różnego rodzaju wyobrażenia agatologiczne, istnieje również wielość religii: „fakt różnorodności systemów religijnych tłumaczony będzie postulowaniem religii jako przestrzeni wyrażania się wyobraźni agatologicznej”29. Podczas jednak gdy wyobrażenia agatologiczne różnią się między sobą, fakt istnienia tych wyobrażeń pozostaje ten sam. Dlatego więc agateizm może stanowić podstawę wielu różnych systemów religijnych. Sytuacja ta może przywodzić na myśl etyczne i polityczne poglądy Rorty’ego, w których dopóki istnieje etyczna solidarność - zgoda na szacunek do drugiego i zasadę nieszkodzenia - dopóty człowiek może wierzyć w i robić, co chce. Podobnie jest w przypadku agateizmu - dopóki istnieje zgoda, że podstawą wszystkich przekonań religijnych jest agateizm, dopóty można wierzyć w cokolwiek. W obu przypadkach wolność (polityczna czy wyznania) gwarantowana jest o ile tylko istnieje pewna etyczna podstawa gwarantująca nieczynienie szkód.

Można zatem stwierdzić, że agateizm stanowi dobrą odpowiedź na postmodernistyczne wezwanie do pluralizmu. Zdaje on sobie sprawę z zagrożeń płynących z religii pierwszego rzędu, które za swą podstawę wydają się raczej brać kategorię prawdy niż dobra i dlatego istnieje w nich skłonność do przemocy. Kiedy jednak fundamentem religii staje się dobro (wprowadzane przez agateizm) problem znika. Niekiedy jednak systemy bazujące na agateizmie mogą sprzeciwiać się episte-

27 Por. ibidem, s. 201.

28 Agateizm (utożsamienie Boga z dobrem) jako podstawa wielu systemów ma swe odzwierciedlenie w historii filozofii. Wydaje się, że systemy religijne Kanta czy Lessinga właśnie takie założenie agateistyczne przyjmują jako fundament tworzonych przez siebie koncepcji. Por. Kant, Religia w obrębie samego rozumu, tłum. A. Bobko, Znak, Kraków 1993; G.E. Lessing, Wychowanie rodzaju ludzkiego, tłum. H. Kahanova, PIW, Warszawa 1959.

29 J. Salamon, Atheism and Agatheism, s. 202. 
mologicznemu argumentowi za pluralizmem, chociaż wydaje się, że sam twórca agateizmu traktuje ten argument poważnie.

Drugą próbą odpowiedzi na normatywne wezwanie do pluralizmu jest pogląd Gianniego Vattimo. Dla prezentowanej przez niego filozofii religii w kontekście pluralizmu istotne są dwa procesy - przezwyciężenia (Verwindung) metafizyki oraz sekularyzacji. Pierwszy ma związek z kontynuowaną przez Vattima tradycją hermeneutyki Heideggera i Gadamera. Przezwyciężenie (w sensie Verwindung) metafizyki i zarazem obalenie klasycznej teorii prawdy związanej, jak już wspomnieliśmy, ściśle z tą tradycją prowadzi wedle Vattima do ponownej możliwości religii. Dzieje się tak dzięki wprowadzeniu interpretacyjnego charakteru poznania, który prócz metafizyki podaje w wątpliwość również wszelkie systemy scjentystyczne, nazywające religię systemem zdań bezsensownych.

Moją tezą - czy lepiej hipotezą - jest to, że jeśli pluralizm filozoficzny poważnie traktuje swój status jako interpretacji, to raz jeszcze spotyka religijną tradycję Zachodu, konkretnie tradycję judeochrześcijańską. Nihilizm umożliwia dialog między filozofią a religią nie tylko w tym sensie, że w dobie nieobecności wielkich, racjonalistycznych, ateistycznych systemów osiemnastego i dziewiętnastego wieku [...] nie ma już dobrego filozoficznego powodu, żeby być ateistą ${ }^{30}$.

Zerwanie z metafizyką, zerwanie z klasycznie pojętą prawdą umożliwia „otwarcie się horyzontów”, tj. pluralizację. Powtórzmy: „hermeneutyka przedstawia się jako myśl zasadniczo przyjazna religii, gdyż wraz ze swą krytyką idei prawdy jako weryfikowalnej zgodności twierdzenia i rzeczy odbiera również podstawy racjonalistycznym, empirystycznym, pozytywistycznym, a nawet idealistycznym i marksistowskim negacjom możliwości doświadczenia religijnego"31.

Oprócz krytyki idei prawdy (metafizyki klasycznej), co sprzyja różnorodności i wpisuje się w pełni w postmodernistyczne nawoływanie do pluralizmu, drugim filarem filozofii religii Vattima jest namysł nad sekularyzacją. Włoski filozof utrzymuje, że sekularyzację należy rozumieć jako fakt pozytywny dla religii, stwarzający możliwości jej zmian czy wręcz pełnej realizacji. Jest to jednak specyficznie pojmowana sekularyzacja. Nie chodzi tu bowiem o odłączenie państwa od Kościoła - używając terminologii Taylora, nie chodzi o sekularyzację polityczną - lecz o wpisujący się w tradycję krytyki metafizyki ruch mający na celu odarcie religii z jej części dogmatycznej. Sekularyzacja nie jest także, wedle Vattima, procesem ateizującym, lecz przekształcającym religię - w tej mierze Vattimo polemizowałby z Taylorem. Najbardziej widoczne staje się to rozumienie sekularyzacji poprzez odwołanie do kategorii kenosis - uniżenia się Boga. Włoski filozof twierdzi, że Bóg uniża się jako Jezus, zarazem pozbawiając się kategorii klasycznej metafizyki (albo przynajmniej sprawiając,

30 G. Vattimo, After Onto-theology, red. M. Wrathall, Cambridge University Press 2003, s. 34 .

31 G. Vattimo, Poza interpretacja, s. 57. 
że to nie one są na pierwszym planie) - nie jest już wszechmocny, wszechwiedzący itd. To, czym jest Bóg po uniżeniu, to jedynie i aż miłość. Można by zadać pytanie: dlaczego Bóg w ogóle miałby robić coś podobnego? Vattimo odpowiada poprzez przekształcenie myśli René Girarda na temat związku przemocy z sacrum. Mówiąc krótko, Bóg pojmowany w kategoriach klasycznej metafizyki (jako wszechmocny, wszechwiedzący, jako prawda) implikuje przemoc ${ }^{32}$. Sekularyzacja natomiast jako proces zaniku sacrum, to w myśl tej interpretacji zanik przemocy powodowanej przez Boga klasycznej metafizyki. Z kolei Jezus (Bóg uniżony) winien być rozumiany jako przede wszystkim miłość, tj. odrzucenie przemocy. „Chrześcijańskie dziedzictwo, które "powraca« w myśli słabej jest głównie chrześcijańskim nakazem miłosierdzia i odrzuceniem przemocy"33. Jedyną granicą wspomnianej sekularyzacji, czyli zarazem jedyną granicą interpretacji (poza którą istnieje całkowita swoboda), jest właśnie miłosierdzie albo sformułowanie św. Augustyna „kochaj i rób co chcesz”34. W tym miejscu można zauważyć, że proponowana przez Vattima droga podobna jest w pewnych aspektach do tego, co mówią przywoływani tu Salamon czy Rorty. We wszystkich trzech koncepcjach podstawę stanowi filozofia praktyczna i chęć zapobiegania przemocy. Jeśli zaś jest to zapewnione, reszta pozostaje kwestią dowolną. Dopóki nikomu nie dzieje się krzywda, można myśleć i działać, jak się chce. Dlatego właśnie Vattimo tak dobitnie podkreśla, że powrót do chrześcijaństwa to powrót do wartości, które za sobą niesie: „istnieje ogólne potępienie rasizmu, rozpowszechniony humanitaryzm odrzucający ideę wojny, poruszony nędzą trzeciego świata i nawołujący do pokoju i solidarności”35.

Religia proponowana przez Gianniego Vattimo również, tak jak agateizm, stanowi odpowiedź na postmodernistyczne normatywne wezwanie do pluralizmu. Z całą powagą traktuje się tu przemoc, którą rodzi jedność czy Bóg pojęty w kategoriach metafizyki klasycznej. Z tego względu wprowadzona i określona zostaje kategoria kenosis, dzięki której umożliwiona zostaje taka interpretacja Jezusa (Boga), która redukuje Go do miłości, uważając to za wypełnienie się chrześcijaństwa. Co więcej myśl religijna włoskiego filozofa respektuje także tezę o interpretacyjnym charakterze poznania, ograniczając możliwe interpretacje jedynie zawołaniem Augustyna „kochaj i rób co chcesz”, co odnosi się również do Biblii.

${ }^{32}$ Ciekawie na temat imperatywu przemocy zawartego w chrześcijaństwie pisze Feuerbach w dziele $O$ istocie chrześcijaństwa; szczególnie w rozdziale „o sprzeczności wiary i miłości”. Por. L. Feuerbach, O istocie chrześcijaństwa, tłum. A. Landman, PWN, Warszawa 1959, s. 413.

33 G. Vattimo, Belief, Stanford University Press 1999, s. 44.

34 Warto również wspomnieć o Biblii w kontekście tezy o braku prawdy obiektywnej. Otóż Vattimo nie przekonuje, że tekst ten nie jest objawiony ani że nie jest prawdziwy. Mówi jedynie, że tak jak każdy tekst należy go interpretować. Granicą zaś tej interpretacji są przytoczone wyżej słowa Augustyna

35 G. Vattimo, Belief, s. 56. 


\section{Zakończenie}

Postmodernizm jest zjawiskiem wielce kontrowersyjnym, jednak nie należy bagatelizować tez, które głosi. Jedna z nich - dotycząca pluralizmu - wydaje się stanowić niezwykle poważny, filozoficzny problem. Oparta jest na dwóch dobrze uzasadnionych argumentach: etycznym i epistemologicznym, przy czym każdy z nich może być rozpatrywany zarówno osobno, jak i w związku z pozostałym. Współczesna recepcja postmodernizmu, a zwłaszcza tezy na temat pluralizmu (religijnego) jest niezwykle krytyczna na gruncie polskim, co jednak nie oznacza, że znalezienie autorów sympatyzujących czy wręcz popierających pluralizm graniczy z niemożliwością. Można wśród nich wymienić przywoływanych wyżej Taylora i Mariańskiego jako autorów niezwiązanych ideowo z postmodernizmem. Pokazują oni, że problem pluralizmu rozumianego pozytywnie jest istotny i należy spróbować znaleźć adekwatną odpowiedź na postulaty postmodernistów. Do takich prób można zaliczyć agateizm Salamona czy filozofię religii Vattima. Obie propozycje wydają się respektować argumenty za pluralizmem. Można również stwierdzić, że koncepcja włoskiego filozofa ukazuje możliwość istnienia poważnej religii, która nie zakłada prawdy obiektywnej, co wielu wydaje się rzeczą niemożliwą ${ }^{36}$.

\section{Literatura}

Bauman Z., Ponowoczesność jako źródło cierpień, Sic!, Warszawa 2004.

Bąk U., Postmodernizm a religia, „Konteksty Społeczne” 2015, t. 3, nr 1(5).

Bramorski J., Postmodernizm jako wyzwanie dla moralności chrześcijańskiej, „Collectanea Theologica” 2002, nr 72(3).

Feuerbach L., O istocie chrześcijaństwa, tłum. A. Landman, PWN, Warszawa 1959.

Hicks S., Explaining Postmodernism: Skepticism and Socialism from Rousseau to Foucault, Scholargy Publishing 2004.

Kant I., Religia w obrębie samego rozumu, tłum. A. Bobko, Znak, Kraków 1993.

Kołakowska A., Czy możliwa jest religia postmodernistyczna?, https://teologiapolityczna.pl/agnieszka-kolakowska-czy-mozliwa-jest-religia-postmodernistyczna [dostęp: 15.06.2021].

Lessing G.E., Wychowanie rodzaju ludzkiego, tłum. H. Kahanova, PIW, Warszawa 1959.

Mariański J., Pluralizm religijny szansq czy zagrożeniem dla Kościoła, „Wrocławski Przegląd Teologiczny” 2001, nr 9(1).

Rorty R., Filozofia a zwierciadło natury, tłum. M. Szczubiałka, Spacja, Fundacja Aletheia, Warszawa 1994.

Rorty R., Przygodność, ironia, solidarność, tłum. W. J. Popowski, Spacja, Warszawa 1996.

Salamon J., Atheism and Agatheism, „European Jurnal for Philosophy of Religion” 2015, $\mathrm{nr} 7(4)$.

\footnotetext{
36 Mam tu na myśli na przykład przywoływanych wyżej Kołakowską czy Bramorskiego
} 
Taylor Ch., A Catholic modernity, Oxford University Press 1999.

Taylor Ch., Maclure J., Secularism and Freedom of Conscience, Harvard University Press 2011.

Vattimo G., After Onto-theology, red. M. Wrathall, Cambridge University Press 2003.

Vattimo G., Belief, Stanford University Press 1999.

Vattimo G., Poza interpretacjq, tłum. K. Kasia, Universitas, Kraków 2011.

Vattimo G., Społeczeństwo przejrzyste, tłum. M. Kamińska, Wydawnictwo Naukowe Dolnośląskiej Szkoły Wyższej Edukacji TWP, Wrocław 2006.

Welsch W., Nasza postmodernistyczna moderna, tłum. R. Kubicki, A. Zeidler-Janiszewska, Oficyna Naukowa, Warszawa 1998. 
